\title{
Change in drinking water quality from catchment to consumers: a case study
}

\author{
G. K. Khadse ${ }^{1}$ P. M. Patni ${ }^{1}$ A. V. Talkhande ${ }^{1}$ P. K. Labhasetwar ${ }^{1}$
}

Received: 23 July 2015/Accepted: 7 September 2016/Published online: 22 September 2016

(C) Springer International Publishing Switzerland 2016

\begin{abstract}
The study was conducted on the status of water supply at Indore through SDWQ. The performance of the Narmada and Devdharan WTPs was assessed from catchment to consumer for consecutive 7 days during three seasons. No significant change in raw water quality was observed on day-to-day basis. During monsoon, the turbidity of raw water was $690-1530$ NTU which was reduced to 0.3-3.7 NTU after treatment. TC and FC were not detected in filtered water. The treated water quality was found within CPHEEO guidelines. At ESR, the residual chlorine was $0.1-0.6 \mathrm{mg} / \mathrm{l}$. During winter, the water from ESR and from consumer ends was free from FC, whereas TC counts at consumer ends were 7-607 CFU/100 ml. During summer, on one occasion, TC and FC counts were found in ESR, whereas at the consumer ends, most of the samples were positive for TC and FC. The variation in bacterial counts amongst the different service reservoirs and consumer ends was due to poor maintenance of ESRs and enroute contamination. The proper maintenance of the distribution network, awareness about the hygienic and sanitary conditions around the public taps and proper storage of water are prerequisites in maintaining safe water supply in the city.
\end{abstract}

Keywords Surveillance of drinking water quality (SDWQ) - Water treatment plant (WTP) - Total coliforms (TC) $\cdot$ Fecal coliforms (FC) · Colony-forming units (CFU) . Permissible limit

G. K. Khadse

gk_khadse@neeri.res.in

1 CSIR-National Environmental Engineering Research Institute, Nagpur 440020, India

\section{Introduction}

Drinking water supply and sanitation are critical water uses for human survival, health and prosperity (WHO 2004; Marobhe et al. 2007). Almost 900 million people lack access to an improved water supply and 2.6 billion to basic sanitation (WHO and UNICEF 2010). The adverse impacts on public health from poor water supply have long been recognized in both developing and developed countries and take the form of disease outbreaks (Esrey et al. 1991; Ford 1999; Payment and Hunter 2001). Water supply access in most developing countries is complex compared to those in developed countries (WHO and UNICEF 2010; Howard and Bartram 2005) resulting in change in water quality from treatment plant to the distribution system. Initiatives to manage the safety of water do not only support public health, but often promote socioeconomic development and well-being as well (WHO 2013). Inspite of significant achievements in water supply and sanitation coverage, many factors render good-quality water unsafe by the time it reaches the consumer. The main problems related to drinking water quality are associated with the conditions of the water supply network (Lehtola et al. 2004; Karavoltsosa et al. 2008; Farooq et al. 2008; Proto et al. 2014), during collection and storage (Andrew et al. 2005), poor operation management and unsatisfactory sanitary practices; so it becomes obligatory to monitor water quality at each stage of delivery (Khadse et al. 2011a, b, c). Water quality management and surveillance practices ensure safe water supply to consumers.

It is essential that the service provider and the consumers shoulder combined responsibility to see that needed programs and policies are taken up to achieve objectives and missions of "providing safe and sufficient water to one and all at minimum cost in terms of optimum utilization of 
available resources, adequate maintenance of existing infrastructures, self sustenance, reduction and loss due to leakage and environmental protections from degradation and pollutions" (WSSP 2004). Surveillance of drinking water quality (SDWQ) is the continuous and vigilant public health assessment and overview of the safety and acceptability of drinking water supplies (WHO 1993). SDWQ at drinking water treatment plant is necessary to avoid risk from chemical and bacteriological pollutants and to assure consumers that drinking water is safe and can be consumed without any risk (Leeuwen 2000). The elements of surveillance include water quality surveillance, study of institutional setup and examination of water for physicochemical and bacteriological parameters. Analysis of these parameters constitutes a risk to human health, others affect the aesthetic quality of the water supplied and others relate to treatment issues (Ratnayaka et al. 2009). SDWQ programs identify those interventions that will result in improvements in water supply that will be protective of public health (Lloyd and Bartram 1991; Lloyd et al. 1991, WHO 1997; Howard 2002) and should identify those communities where water supply improvements will deliver the greatest health gain (Lloyd et al. 1991). Public health protection aspects of waterworks should ensure that each component of the system, viz. source, treatment, conveying main, storage and distribution, functions without risk of failures.

The SDWQ also involves inspection of site and sanitary condition of installations. The activities of SDWQ include assessment of design, commissioning and O\&M of source, treatment, storage and distribution. The sampling and analysis of water from source to distribution are the main components of SDWQ. The water analysis laboratories of water supply agency, financial and manpower structure are in the purview of SDWQ. The SDWQ is to seek the answer to the question-is the water supply agency in a position to give the specified quality of water to total population within reasonable cost? The SDWQ includes all the activities to seek answer to these questions. It is necessary to ascertain the present status of drinking water quality being supplied in urban areas and to evolve a suitable strategy for future planning for SDWQ. In view of these, in the present paper, the intake water quality of treatment plants, at different treatment stages and at consumer end, was monitored for three different seasons to assess the drinking water quality status of Shimla city which may help in taking appropriate measures for safe drinking water supply to the city.

\section{Study area}

Indore city is the commercial capital of Madhya Pradesh in India and lies at latitude $22^{\circ} 44^{\prime} \mathrm{N}$ and longitude $75^{\circ} 50^{\prime} \mathrm{E}$. There are two water treatment plants (WTPs) viz. Narmada and Devdharan, which supply treated water to the city. Public Health Engineering Department (PHED) is responsible for O\&M of Narmada WTP, and Municipal Corporation is looking after Devdharan WTP and water distribution network of the city. The capacity details of the WTPs are provided in Table 1. Both the plants follow the conventional method of treatment like addition of coagulant, flash mixing, flocculation, sedimentation, filtration and chlorination. Salient features of WTPs are given in Table 1 and the flow sheets of WTPs are given in Figs. 1 and 2. The cases of gastroenteritis (296), hepatitis (165), diarrhea (9), jaundice (35) and typhoid (9) were reported during the year 2000-2002 in the city. The water-supplying authority takes the preventive measures in a routine manner. No epidemic due to water-born diseases was reported during the recent past.

\section{Methodology}

Criteria for selecting sampling locations are envisaged with a view to examine water quality starting from raw water at source to consumers end including all the intermediate

Table 1 Salient features of WTPs

\begin{tabular}{lllll}
\hline Treatment plant & Location & Raw water source & $\begin{array}{l}\text { Distance } \\
(\mathrm{km})\end{array}$ & $\begin{array}{l}\text { Design capacity } \\
(\mathrm{MLD})\end{array}$ \\
\hline $\begin{array}{c}\text { Narmada WTP, } \\
\text { phase I \& phase II } \\
\begin{array}{l}\text { Devdharan WTP } \\
\hline\end{array}\end{array}$ & Jalud & Narmada river & 70 & 171 \\
\hline
\end{tabular}

Fig. 1 Flow diagram of Narmada WTP

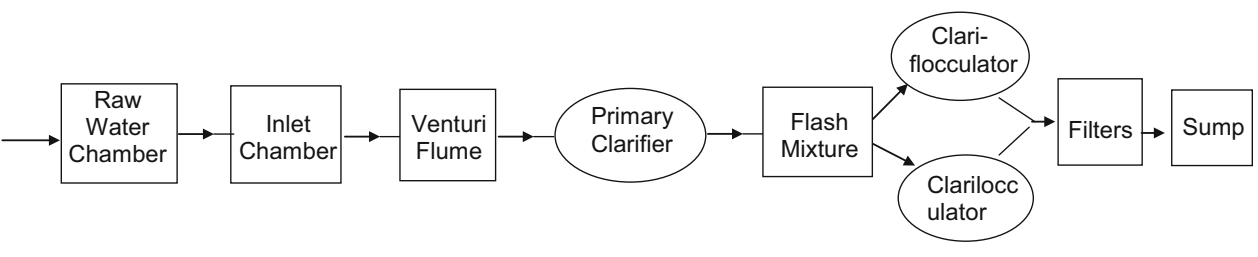


Fig. 2 Flow diagram of Devdharan WTP

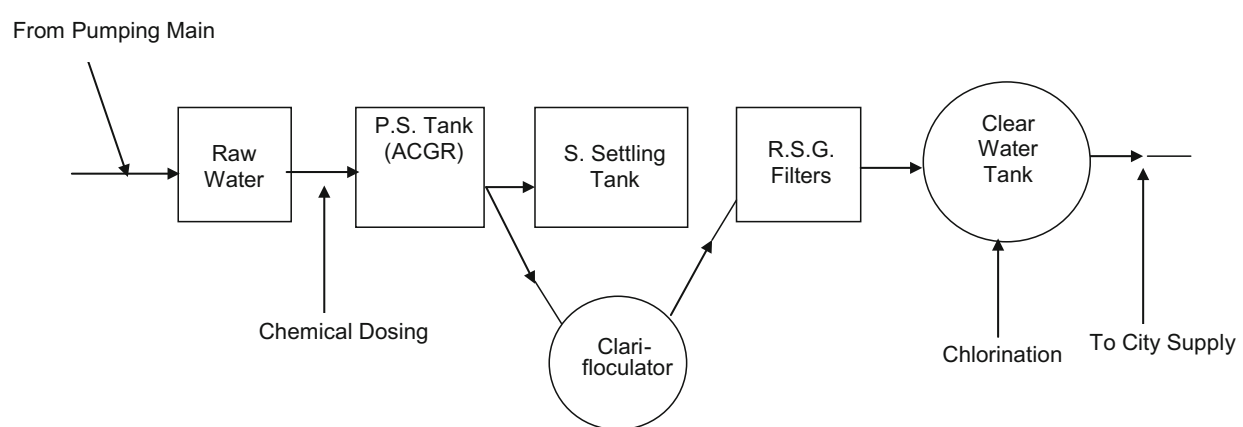

Table 2 Water quality at WTPs

\begin{tabular}{|c|c|c|c|c|c|c|c|c|c|c|c|}
\hline \multirow[t]{3}{*}{ S. no. } & \multirow[t]{3}{*}{ Parameters } & \multicolumn{4}{|l|}{ Winter } & \multirow{2}{*}{\multicolumn{2}{|c|}{$\frac{\text { Summer }}{\text { Narmada WTP }}$}} & \multirow{2}{*}{\multicolumn{2}{|c|}{$\frac{\text { Monsoon }}{\text { Narmada WTP }}$}} & \multicolumn{2}{|c|}{ IS:10500:1991 } \\
\hline & & \multicolumn{2}{|c|}{ Narmada WTP } & \multicolumn{2}{|c|}{ Devdharan WTP } & & & & & \multirow{2}{*}{$\begin{array}{l}\text { Desirable } \\
\text { limit }\end{array}$} & \multirow{2}{*}{$\begin{array}{l}\text { Permissible } \\
\text { limit }\end{array}$} \\
\hline & & $\begin{array}{l}\text { Raw } \\
\text { water }\end{array}$ & $\begin{array}{l}\text { Sump } \\
\text { water }\end{array}$ & $\begin{array}{l}\text { Raw } \\
\text { water }\end{array}$ & $\begin{array}{l}\text { Sump } \\
\text { water }\end{array}$ & $\begin{array}{l}\text { Raw } \\
\text { water }\end{array}$ & $\begin{array}{l}\text { Sump } \\
\text { water }\end{array}$ & $\begin{array}{l}\text { Raw } \\
\text { water }\end{array}$ & $\begin{array}{l}\text { Sump } \\
\text { water }\end{array}$ & & \\
\hline 1 & $\mathrm{pH}$ & $7.8-8.2$ & $8.1-8.3$ & $7.8-8$ & $7.3-7.4$ & $8.3-8.4$ & $8.2-8.3$ & $7.4-7.6$ & $7.7-7.9$ & $6.5-8.5$ & No relaxation \\
\hline 2 & Temperature $\left({ }^{\circ} \mathrm{C}\right)$ & $19-20$ & $19-20$ & $18-20$ & $18-20$ & $29-30$ & $29-30$ & $30-31$ & - & - & - \\
\hline 3 & Turbidity (NTU) & $0.6-1.0$ & $0.4-0.7$ & $3-5.2$ & $1.4-2.8$ & $0.7-1.8$ & $0.56-1.3$ & $690-1530$ & $0.3-3.7$ & 5 & 10 \\
\hline 4 & Cond. (mS/l) & $230-235$ & 240 & 235 & 235 & $242-246$ & $243-246$ & $150-200$ & $155-185$ & - & - \\
\hline 5 & TDS (mg/l) & 140 & 145 & $135-140$ & 140 & 146 & $146-148$ & $90-120$ & $95-115$ & 500 & 2000 \\
\hline 6 & T. alk (mg/l) & $113-117$ & $117-120$ & $92-97$ & $84-90$ & $136-144$ & $140-148$ & $75-96$ & $70-85$ & 200 & 600 \\
\hline 7 & T. hard (mg/l) & 104-107 & $106-110$ & $87-92$ & $87-90$ & $100-104$ & $100-104$ & $78-112$ & $82-104$ & 300 & 600 \\
\hline 8 & $\mathrm{Ca}(\mathrm{mg} / \mathrm{l})$ & 26 & $26-28$ & $21-22$ & $21-22$ & $19-21$ & $19-21$ & $22-30$ & $21-30$ & 75 & 200 \\
\hline 9 & $\mathrm{Mg}(\mathrm{mg} / \mathrm{l})$ & $9.5-10.1$ & $9.5-9.9$ & $8.3-8.9$ & $7.8-8.6$ & $10.8-12.7$ & $11.6-13.7$ & $5-10$ & $6-8$ & 30 & 100 \\
\hline 10 & $\mathrm{Cl}(\mathrm{mg} / \mathrm{l})$ & 12 & 12 & 16 & 16 & $12-14$ & $12-16$ & 10 & 12 & 250 & 1000 \\
\hline 11 & $\mathrm{SO}_{-4}(\mathrm{mg} / \mathrm{l})$ & 5 & 5 & 12 & $16-18$ & 6 & $5-7$ & $12-17$ & $15-20$ & 200 & 400 \\
\hline 12 & $\mathrm{NO}_{3}(\mathrm{mg} / \mathrm{l})$ & 2 & $2-3$ & 3 & 2 & $1.7-2.7$ & $1.1-2.9$ & $3-4$ & $3-4$ & 45 & 100 \\
\hline 13 & $\mathrm{PO}_{4}(\mathrm{mg} / \mathrm{l})$ & ND & ND & ND & 0.02 & ND-0.06 & $0.5-0.7$ & ND-0.03 & ND & - & - \\
\hline 14 & $\mathrm{~F}(\mathrm{mg} / \mathrm{l})$ & 0.01 & 0.01 & 0.02 & 0.02 & $0.17-0.18$ & 0.18 & 0.2 & 0.2 & 1.0 & 1.5 \\
\hline 15 & $\mathrm{Na}(\mathrm{mg} / \mathrm{l})$ & 15 & 15 & $16-17$ & 17 & 17 & 17 & 6 & 6 & - & - \\
\hline 16 & $\mathrm{~K}(\mathrm{mg} / \mathrm{l})$ & $1-2$ & 1 & 5 & 5 & 2 & 2 & 2 & 2 & - & - \\
\hline 17 & $\mathrm{DO}(\mathrm{mg} / \mathrm{l})$ & $8.6-9.1$ & - & $6.2-7.6$ & - & $7.1-7.4$ & - & $7.0-7.2$ & - & - & - \\
\hline 18 & Residual $\mathrm{Cl}(\mathrm{mg} / \mathrm{l})$ & - & $0.4-0.15$ & - & $1.5-2$ & - & $0.2-0.8$ & - & $0.8-2.0$ & 0.2 & - \\
\hline 19 & $\mathrm{TC}(\mathrm{CFU} / 100 \mathrm{ml})$ & $30-73$ & ND & $13-310$ & ND & ND-60 & ND & $120-250$ & ND & Nil & Nil \\
\hline 20 & $\mathrm{FC}(\mathrm{CFU} / 100 \mathrm{ml})$ & ND & ND & ND & ND & ND-8 & ND & $10-140$ & ND & Nil & Nil \\
\hline
\end{tabular}

$N D$ not detected; not done

stages of treatment unit, distribution network and consumer ends (from household tap during water supply) (Tables 2, $3)$. The city has intermittent water supply for $2-4 \mathrm{~h}$ daily. To examine the performance of WTPs, the samples of raw, settled, and filtered water were collected during summer, monsoon and winter seasons for 7 consecutive days from Narmada WTP, whereas Devdharan WTP was assessed during winter only due to non-functioning of WTP during summer and monsoon.

The raw water and treated water samples were collected and analysed for physicochemical parameters and bacteriological quality. The settled water was collected from the overflow of the clariflocculator/settling tank of the WTPs and examined for turbidity and sulphate. The filtered water was collected from the combined channel of the filters after filtration and analysed for turbidity, sulphate, and bacteriological quality. Final treated water after chlorination was collected from the sump of each WTP. To assess the enroute bacteriological contamination in distribution network, water samples were collected from service reservoirs and distribution network for bacteriological analysis. The samples were also collected from consumer end to see the quality of water supplied to the consumer. To monitor the water quality at consumer end, samples from 21 ESR and 21 representative consumer ends were evaluated. 


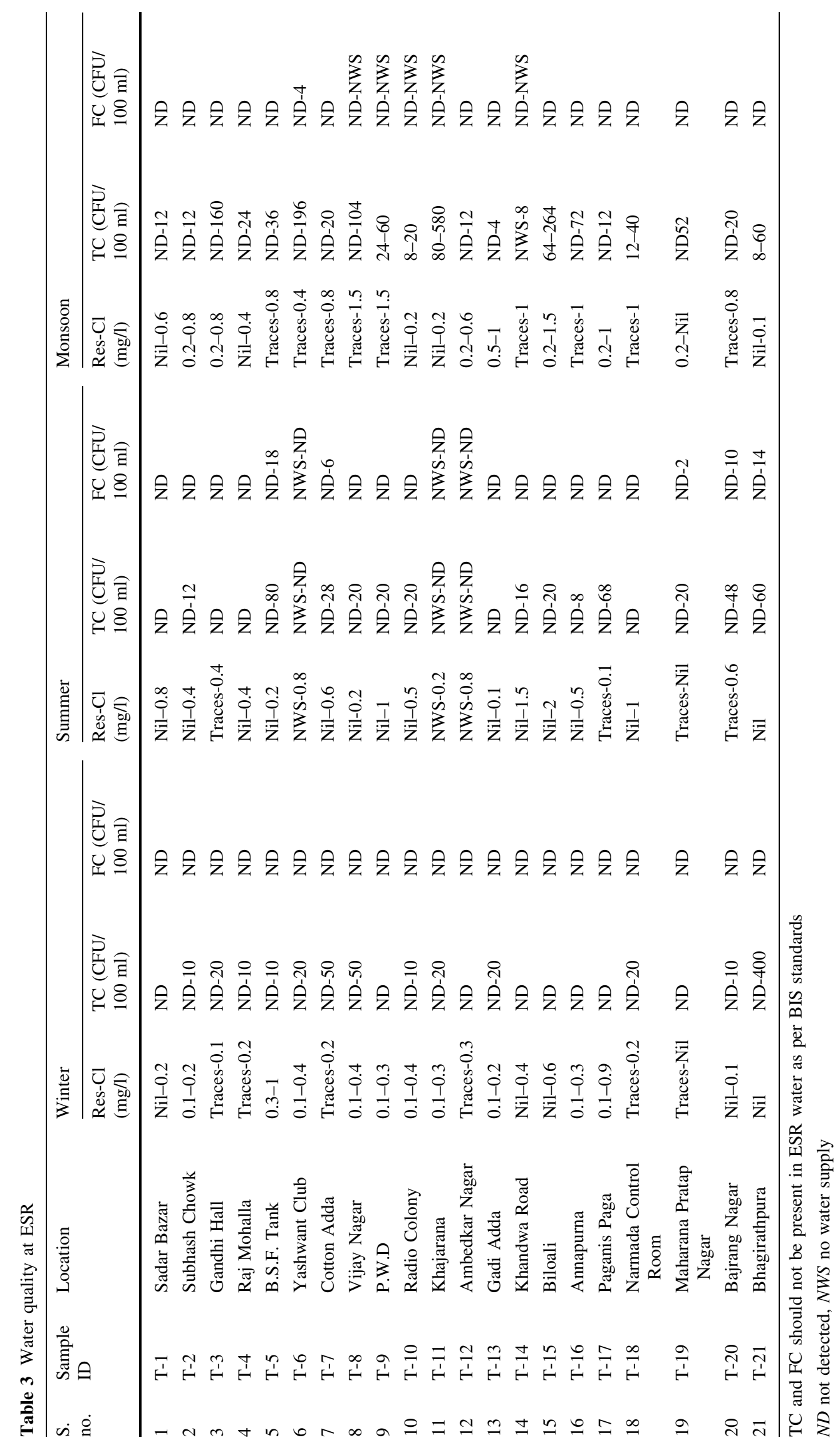


The water quality parameters such as temperature $\left({ }^{\circ} \mathrm{C}\right)$, $\mathrm{pH}$, conductivity (EC) and dissolved oxygen (DO) were measured in the field. For other parameters, samples were preserved by adding appropriate reagents. Samples were filtered and stored in plastic bottles and analysed for major cations $(\mathrm{Ca}, \mathrm{Mg}, \mathrm{Na}, \mathrm{K})$ and major anions $\left(\mathrm{SO}_{4}, \mathrm{Cl}, \mathrm{PO}_{4}\right.$, $\mathrm{NO}_{3}$ ) as per standard methods (APHA, AWWA, WPCF 1998, 2005). Sodium and potassium were determined by flame photometry. Chloride, total hardness, and total alkalinity were analysed by volumetric methods. Sulphate, nitrate and phosphate were estimated by spectrophotometric technique. Bacteriological tests for total coliform and fecal coliform were undertaken by membrane filter (MF) technique. Knowledge, Attitude and Practice (KAP) survey was conducted which pertains to defined specific and measurable campaign objectives based on the problems identified by the agency. The KAP survey objectives have been achieved separately through a set of questionnaires designed separately for general public, health agencies and managers of water supply agencies. People from different economic and literacy levels comprising various age groups and gender from slum area, civil area, market area were covered during the survey. About 100 people were surveyed for their opinions about drinking water supply in the city.

\section{Results and discussions}

\section{Water quality at WTPs}

The analytical results for the physicochemical and bacteriological parameters of the water samples collected during three seasons are reported in Tables 2, 3 and 4 .

\section{Narmada WTP}

During winter, it was observed that phase I and phase II units of the WTP were overloaded to the extent of $20 \%$. The performances of both the units were satisfactory as the raw water quality was fairly good. Alum/PAC addition was discontinued due to low turbidity of raw water. Bacteriological quality of raw water showed the presence of TC in the range of 30-73 CFU/100 ml, while FC was not detected (Table 2). TC in the filtered water samples of phase I and phase II units was up to $27 \mathrm{CFU} / 100 \mathrm{ml}$ and up to $113 \mathrm{CFU} /$ $100 \mathrm{ml}$, respectively, and FC was not detected (Table 2).

During summer, the turbidity of raw water was $0.7-1.8$ NTU. As the raw water quality was fairly good, Alum/PAC addition was not practised. In raw water, TC and FC were up to $60 \mathrm{CFU} / 100 \mathrm{ml}$ and up to $8 \mathrm{CFU} / 100 \mathrm{ml}$, respectively, (Table 2). TC in the filtered water sample of phase I and phase II units was up to 44 and $16 \mathrm{CFU} / 100 \mathrm{ml}$, respectively (Table 2). FC was not detected in the filtered water.
During monsoon, the river was flooding and the turbidity of raw water was 690-1530 NTU. Primary settling tank brought down the turbidity of raw water to some extent. The applied PAC dose was @20 mg/L and supplemented with $0.1 \mathrm{mg} / \mathrm{L}$ dose of catflock. Finished water turbidity was $0.3-3.7$ NTU. TC and FC in raw water were in the range of 100-250 and $10-140 \mathrm{CFU} / 100 \mathrm{ml}$, respectively (Table 2). In filtered water of phase I unit, TC and FC counts were $50-300 \mathrm{CFU} / 100 \mathrm{ml}$ and up to $80 \mathrm{CFU} / 100 \mathrm{ml}$, respectively. In filtered water of phase II unit, TC was up to $20 \mathrm{CFU} / 100 \mathrm{ml}$ and no $\mathrm{FC}$ was observed (Table 2). The treated water quality of the plants during all the seasons was found within the desirable limit as per BIS standards (BIS 1991).

\section{Devdharan WTP}

The raw water turbidity during winter was in the range of 3.0-5.2 NTU, whereas the turbidity of settled and filtered water was in the range of 1.2-3 NTU and 2.4-2.8 NTU, respectively. Settled and filtered water turbidity indicated poor settling of the flocks after alum dosing and malfunctioning of filter beds which may be due to improper back washing. The alum dose was not properly regulated, and the overall maintenance of the plant was not satisfactory. In raw water, TC counts were in the range of 13-310 CFU/ $100 \mathrm{ml}$ and FC was not detected (Table 2). In filtered water, TC was up to $80 \mathrm{CFU} / 100 \mathrm{ml}$ and FC was not detected (Table 2). The finished water quality was within the desirable limit as per BIS standards. During summer and monsoon, the Devdharan WTP was found closed due to non-availability of raw water in Yashwant Sagar Dam.

\section{Water quality of distribution system}

After conventional treatment, water from WTP is pumped to elevated service reservoirs (ESR) for distribution. The water quality of 21 ESR (Table 3 ) and 21 consumer ends (Table 4) were tested for residual chlorine and samples were analysed for bacteriology. The chlorine solution is added in all the ESR before distribution, and the residual chlorine was found in the range of $0.1-0.6,0-1$ and $0-1.0 \mathrm{mg} / \mathrm{l}$ during winter, summer and monsoon, respectively.

During winter, FC was not detected in any water sample from ESR and consumer end, while TC count at consumer ends was 7-607 CFU/100 ml. During summer, on one occasion, TC and FC counts in ESR (T-5) were 80 and $18 \mathrm{CFU} / 100 \mathrm{ml}$, respectively. The TC counts present in $\mathrm{T}-7$ and T-20 samples were in the range of 28-48 CFU/ $100 \mathrm{ml}$ and FC counts were in the range of 4-10 CFU/100. At the consumer ends, out of 21 samples, most of the samples were positive both for $\mathrm{TC}$ and $\mathrm{FC}$ as 76 and $12 \mathrm{CFU} / 100 \mathrm{ml}$, respectively. In monsoon, it was observed 


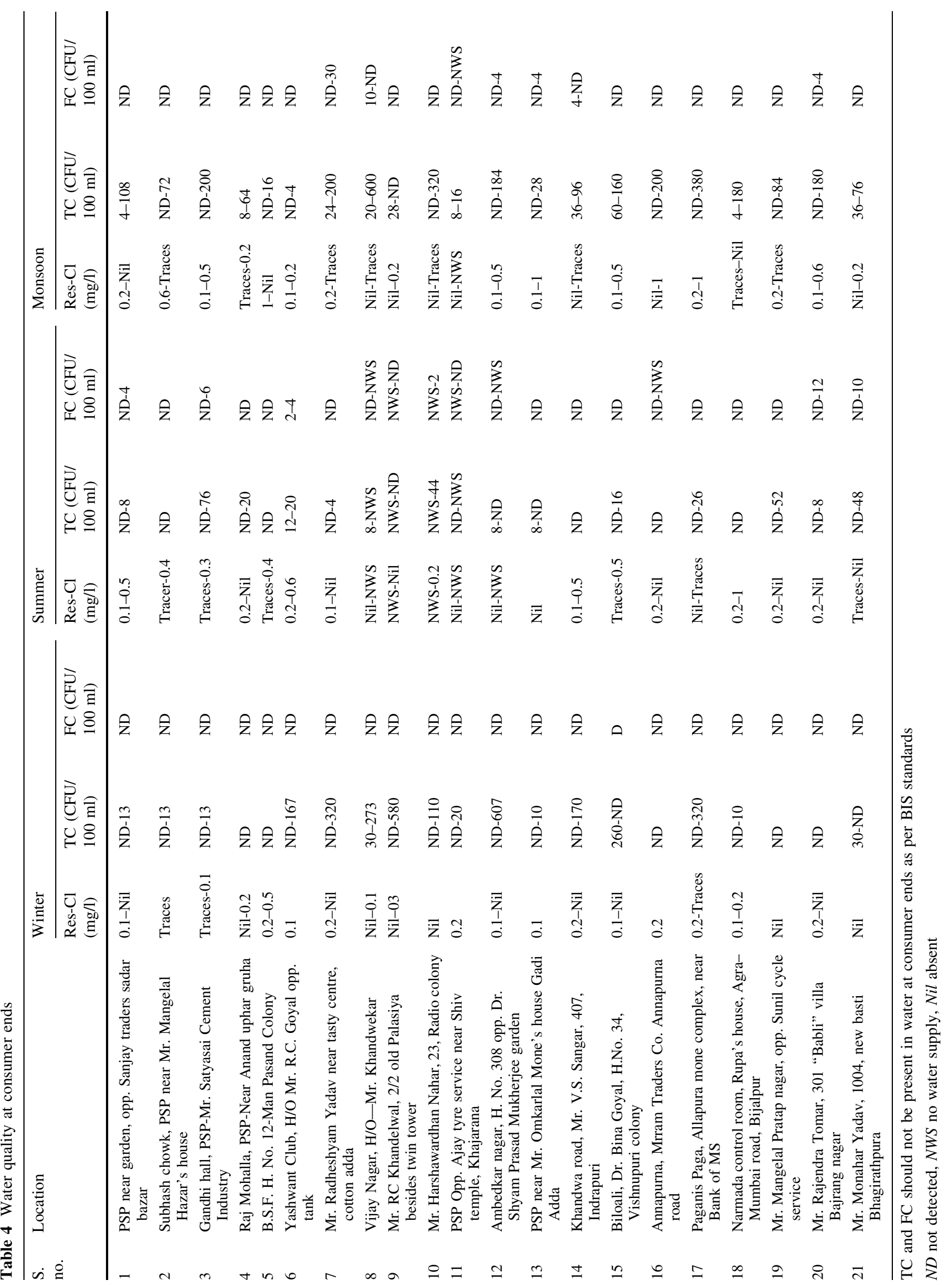


that in samples T-6, T-8, T-11 and T-15, TC was up to 196 , 104, 580 and $264 \mathrm{CFU} / 100 \mathrm{ml}$. At consumer ends, it was observed that TC was up to $700 \mathrm{CFU} / 100 \mathrm{ml}$ and $\mathrm{FC}$ was $48 \mathrm{CFU} / 100 \mathrm{ml}$. Presence of TC and FC indicated occasional enroute contamination in the ESR and distribution system.

\section{KAP survey}

\section{Perceived state of drinking water pollution}

The water quality is good in the opinion of $60 \%$ of consumers. There is a regular water quality control program conducted by the field staff of the water supply agency by carrying out random water sampling of ESR and consumer ends.

\section{Awareness of the SDWQ and information on drinking water standards}

Awareness of the SDWQ program amongst general public is $20 \%$; in water works personnel, it is $35 \%$, and in health agencies, it is $30 \%$. Awareness of information on drinking water quality standard was $40 \%$ amongst general public, $80 \%$ amongst waterworks personnel and $90 \%$ amongst health agency staff.

\section{Information on private water supplies}

A total of $20 \%$ of the consumer amongst general public informed that they use private water supply through tube wells to meet their additional water demand.

\section{Accountability for the efficient and effective delivery of water supply}

$10 \%$ of the consumers amongst general public have indicated the satisfaction towards water supply, while $90 \%$ supply efficiency and effective delivery of finished water were reported by $60 \%$ waterworks personnel.

\section{Knowledge of individuals/institution with water supply agency services}

A total of $50 \%$ of the consumers amongst general public, especially educated people, were aware of water supply agency services.

\section{Procedure for the complaints against drinking water supply}

$45 \%$ of the consumers indicated prompt action of waterworks personnel towards the lodged complaint regarding drinking water supply.

\section{Knowledge of sanitary survey}

About $80 \%$ of the respondents amongst general public were found aware of cleaning practices and health aspects related to sanitary practices.

\section{Knowledge of preventive measures and health education}

$65 \%$ of the respondents were aware about the preventive measures to be taken to prevent the water-borne diseases. Yet, there is a need to impart health education to common people, especially illiterates and women.

\section{Status of quality control and surveillance}

The raw water sources were well protected from pollution in catchments. Alum bricks are kept in the raw water inlet channel. The dose of chlorine is arbitrary due to absence of dose regulating system, and dosing is done based on experience of the operator. The O\&M of Narmada WTP is satisfactory, whereas Devdharan WTP is lacking in O\&M. The staff of IMC looks after leakages and maintenance of distribution network. PHED laboratory undertakes the water analysis for the samples sent by the Municipal Corporation who is having well-equipped central water testing laboratory. Laboratory facilities are provided at Narmada WTP, but laboratory at Devdharan WTP did not have adequate equipment/instruments. Raw and treated water quality for $\mathrm{pH}$, alkalinity, hardness, sulphate and residual chlorine are analysed at Narmada WTP and records are maintained properly.

Regular water quality control program is practised by water supply agency by carrying out random water sampling of ESRs and consumer ends. There is no organized leak detection program, and the leakages are repaired on the basis of public complaints and as noticed by water supply personnel. SDWQ program was not in practice. During the study period, 40-50\% water samples for TC and about $20 \%$ water samples for FC were found positive from distribution system; hence, there exists an urgent need to create the infrastructural facility to carry out SDWQ.

\section{Conclusion}

The drinking water supply at Indore was assessed at raw water sources, treatment stages, distribution network and consumer ends. From the present study, it is observed that water supplied through the distribution network is of good physicochemical quality; however, 40-50\% water samples for TC and about $20 \%$ water samples for FC were found positive from consumer ends. No significant change in physicochemical parameters of raw water quality was 
observed on a day-to-day basis. The city had an intermittent water supply. Therefore, during non-supply hours, due to back suction through leakages/damages/faulty jots in the supply lines, some insanitary material might be entering into the pipelines and carried up to the consumer ends, when supply resumes. In the places where the fecal contamination was present at the consumer end, the necessary precautionary measures need to be undertaken to avoid any adverse impact on health. The proper maintenance of the distribution network, awareness about the hygienic and sanitary conditions around the public taps and proper storage of water will definitely help in maintaining water quality within the limits of potable water standards. Thus, the surveillance of water supply and in-time measures to control the contamination along with people's participation will lead to safety and better health of the community.

\section{Recommendations}

- Instruments/equipments for flow measurement and head loss indicator need to be repaired and maintained.

- Monitor coagulant dosing to avoid carryover of microflocs.

- Improve backwash to avoid scum formation in settling tank, filter beds.

- Ensure requisite quantity of residual chlorine with proper chlorine dose.

- Upgradation of water testing laboratories at treatment plant.

- O\&M aspects of WTPs need due attention.

\section{References}

Andrew FT, Carter RC, Sean FT (2005) Mechanisms leading to postsupply water quality deterioration in rural Honduran communities. Int J Hyg Env Health 208(3):153-161. doi:10.1016/j.ijheh. 2005.01.024

APHA, Awwa, WPCF (1998) Standard methods for examination of water and wastewater, 20th edn. American Public Health Association, Washington, DC

APHA, Awwa, WPCF (2005) Standard methods for examination of water and wastewater, 21st edn. American Public Health Association, Washington, DC

BIS:10500 (1991) Bureau of Indian Standards (BIS), Guidelines for drinking water quality standards

Esrey SA, Potash JB, Roberts L, Shiff C (1991) Effects of improved water supply and sanitation on ascariasis, diarrhoea, dracunculiasis, hookworm infection, schistosomiasis, and trachoma. Bull World Health Organization 69(5):609-621

Farooq S, Hashmi I, Qazi IA, Qaiser S, Rasheed S (2008) Monitoring of coliforms and chlorine residual in water distribution network of Rawalpindi, Pakistan. Environ Monit Assess 140:339-347. doi:10.1007/s10661-007-9872-2

Ford TE (1999) Microbiological safety of drinking water: United States and global perspectives. Environ Health Perspect 107(S1):191-206
Howard G (ed) (2002) Water supply surveillance: a reference manual. WEDC, Loughborough

Howard G, Bartram J (2005) Effective water supply surveillance in urban areas of developing countries. J Water Health 3(1):31-43

Karavoltsosa S, Sakellaria A, Mihopoulosb N, Dassenakisa M, Scoullosa MJ (2008) Evaluation of the quality of drinking water in regions of Greece. Desalination 1-3:317-329. doi:10.1016/j. desal.2007.06.013

Khadse GK, Kalita M, Pimpalkar SN, Labhsetwar PK (2011a) Drinking water quality monitoring and surveillance for safe water supply in Gangtok, India. Environ Monit Assess 178 (1-4): 401-414, 1573-2959. doi:10.1007/s10661-010-1699-6

Khadse GK, Kalita M, Pimpalkar SN, Labhsetwar PK (2011b) Surveillance of drinking water quality for safe water supply-a case study from Shillong India. Water Resour Manag 25:3321-3342. doi:10.1007/s1269-011-9858-2

Khadse GK, Kalita M, Labhsetwar PK (2011c) Change in drinking water quality from source to point-of-use and storage: a case study from Guwahati. Environ Monit Assess, India. doi:10.1007/ s10661-011-2344-8

Leeuwen FXRV (2000) Safe drinking water: the toxicologist's approach. Food Chem Toxicol 38(1):S51-S58

Lehtola MJ, Nissinenb TK, Miettinena IT, Martikainenc PJ, Vartiainen $T$ (2004) Removal of soft deposits from the distribution system improves the drinking water quality. Water Res 38(3):601-610. doi:10.1016/j.watres.2003.10.054

Lloyd B, Bartram J (1991) Surveillance solutions to microbiological problems in water quality control in developing countries. Wat Sci Technol 24(2):61-75

Lloyd B, Bartram J, Rojas R, Pardon M, Wheeler D, Wedgewood K (1991) Surveillance and improvement of Peruvian drinking water supplies. Robens Institute, DelAgua and ODA, Guildford

Marobhe NJ, Renman G, Jacks G (2007) The study of water supply and traditional water purification knowledge in selected rural villages in Tanzania. Indigenous knowledge systems and sustainable development: relevance for Africa, Emmanuel K. Boon and Luc Hens, Kamla-Raj Enterprises. Tribes and Tribals. vol 1, Chapter 11, 111-120

Payment P, Hunter PR (2001) Endemic and epidemic infectious intestinal disease and its relationship to drinking water. In: Fewtrell L, Bartram J (eds) Water quality: guidelines, standards and health. IWA Publishing, London, pp 61-88

Proto A, Zarrella I, Capacchione C, Motta O (2014) One-year surveillance of the chemical and microbial quality of drinking water shuttled to the Eolian Islands. Water 6:139-149. doi:10. 3390/w6010139

Ratnayaka DD, Brandt MJ, Johnson KM (2009) Chemistry, microbiology and biology of water. Chapter 6, water supply, 6th edn. p 195-266. doi:10.1016/B978-0-7506-6843-9.00014-7

WHO (1993) Guidelines for drinking-water quality, vol 1. Recommendations, 2nd edn. World Health Organization, Geneva

WHO (1997) Guidelines for drinking-water quality, vol 3. Surveillance and control of community water supplies, 2nd edn. World Health Organization, Geneva

WHO (2004) Guidelines for drinking-water quality, 3rd edn. World Health Organization, Geneva

WHO (2013) Water quality and health strategy 2013-2020. http:// www.who.int/watersanitation_health/publications/2013/water_ quality_strategy/en/index.html

WHO, UNICEF (2010) Progress on drinking water and sanitation: 2010 update. World Health Organization, Geneva

WSSP (2004) Gangtok-Shillong and South Asia Regional, water supply and sanitation program (WSSP) Citizen's Charter of Water Security \& Public Health Engineering Department, 25 July 2004 EEG301-ID05-004 